\title{
[DLys $\left.{ }^{6}\right]$-LHRH-Curcumin Conjugate Inhibits Pancreatic Cancer Cell Growth in vitro and in vivo
}

\author{
S. Aggarwal ${ }^{1,{ }^{\star}}$, M. W. Ndinguri ${ }^{2, \#}$, R. Solipuram ${ }^{1}$, N. Wakamatsu ${ }^{3}$, R.P. Hammer ${ }^{2, \#}$, D. \\ Ingram ${ }^{4}$, and $\mathbf{W}$. Hansel ${ }^{1}{ }^{,}{ }^{*}$ \\ ${ }^{1}$ William Hansel Cancer Prevention Laboratory, Baton Rouge, Louisiana 70808 \\ 2Department of Chemistry, Louisiana State University, Baton Rouge Louisiana 70803 \\ ${ }^{3}$ Department of Pathobiological Sciences, School of Veterinary Medicine, Louisiana State \\ University, Baton Rouge, Louisiana 70803 \\ ${ }^{4}$ Cell biology and Imaging Core, Pennington Biomedical Research Center, Baton Rouge, \\ Louisiana 70808
}

\begin{abstract}
Pancreatic ductal adenocarcinomas are invariably lethal and developing effective treatments that have minimal side effects is a challenge. Previous studies from our lab have shown that conjugates of cell membrane disrupting lytic peptides and luteinizing hormone releasing hormone (LHRH) target and destroy human prostate and breast cancer cells in xenografts in the nude mouse model ${ }^{1,2}$ which express LHRH receptors. The objectives of this study were to synthesize a bioconjugate of LHRH analog ([DLys $\left.{ }^{6}\right]$-LHRH) and a dietary micro-chemical (Curcumin) and test the hypothesis that $\left[\mathrm{DLys}^{6}\right]$-LHRH-Curcumin targets and inhibits pancreatic cancer cell growth in vitro and in vivo. In in vitro studies, we determined by confocal microscopy, flow cytometry analysis and RT-PCR that MIAPaCa-2, Panc- 1 and BxPC-3 pancreatic cancer cell lines express LHRH receptors. [DLys ${ }^{6}$ ]-LHRH-Curcumin inhibited cell proliferation of pancreatic cancer cell lines and induced apoptotic cell death $(\mathrm{p}<0.05)$. Apoptosis was induced by cleavage of PARP and Caspase-3. The activity of [DLys $\left.{ }^{6}\right]$-LHRH-Curcumin was equal to free Curcumin at equimolar concentrations in vitro. Unlike Curcumin itself, the [DLys $\left.{ }^{6}\right]-\mathrm{LHRH}-\mathrm{Curcumin}$ conjugate is water soluble which allows its intravenous administration. In two in vivo studies, $\left[\right.$ DLys $\left.^{6}\right]$-LHRH-Curcumin given intravenously caused a significant $(\mathrm{p}<0.01)$ reduction in tumor weights and volumes, and free Curcumin given by gavage at an equal dose failed to cause a significant reduction in tumor weights and volumes in the nude mouse pancreatic cancer model. [DLys $\left.{ }^{6}\right]$-LHRH-Curcumin treatment enhanced apoptosis compared to [DLys $\left.{ }^{6}\right]$-LHRH and vehicle treated controls in tumor tissue. In conclusion, $\left[\mathrm{DLys}^{6}\right]$-LHRH-Curcumin may be useful in treating pancreatic cancer.
\end{abstract}

\footnotetext{
*Authors to whom all the correspondence, proof, and request for reprints should be addressed. Sita.Aggarwal@pbrc.edu, william.hansel@pbrc.edu.

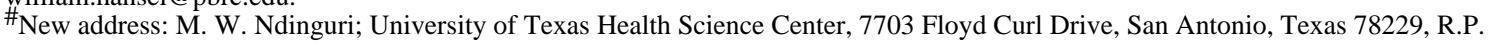
Hammer; New England Peptide, Gardner, Massachusetts 01440

Conflict of interest: There is no potential conflict of interest to the work described.
} 


\section{Keywords}

Pancreatic cancer; Curcumin; [DLys $\left.{ }^{6}\right]$-LHRH-Curcumin; luteinizing hormone releasing hormone receptor; tumor growth inhibition

\section{Introduction}

Pancreatic cancer is a highly lethal disease with extremely poor prognosis. It has been estimated that 42,470 new cases and 35,240 deaths in U.S. were due to pancreatic cancer in $2009^{3}$. The 5-year relative survival rate for all stages is approximately four percent. Current treatments, such as radiation, surgery, chemotherapy, or a combination of these modalities have had little impact on survival rate in pancreatic cancer patients. One of the major problems in cancer chemotherapy is the severe toxic side effects of anti-cancer drugs designed to destroy rapidly dividing cells, including those found in healthy tissues. These severe side effects often result in dose reduction, treatment delay or discontinuance of therapy. To overcome these limitations, various systems have been developed to deliver anticancer drugs used in chemotherapy to increase solubility, decrease adverse side effects, and limit nonspecific activity ${ }^{4,5}$. Targeted anticancer drug delivery systems are an advanced approach for delivering the anticancer drugs. Cancer cell targeting can be achieved by adding several targeting moieties to the drug delivery system, such as receptor ligands ${ }^{6}$, sugars ${ }^{7}$, lectins ${ }^{8}$, antibodies ${ }^{9}$, hormones and hormone analogues, specifically directed to receptor binding sites on cancer cells ${ }^{10}$.

It is evident from numerous studies that expression of gonadotropin-releasing hormone (GnRH), also called luteinizing hormone releasing hormone (LHRH) and LHRH receptor (LHRHR) are part of an autocrine/paracrine regulatory system of cell proliferation found in a number of human maligant tumors, including cancers of endometrium, ovary, and breast ${ }^{11}$. Available data strongly suggest that about $50 \%$ of breast cancers ${ }^{12}$ and $80 \%$ of ovarian and endometrial cancers express high affinity binding sites for LHRH ${ }^{13}$. In these cancers, in vitro proliferation can be inhibited by agonist or antagonist analogues of LHRH in a dose and time dependent manner ${ }^{11,14}$. Although pancraetic cancers express LHRH receptors, and normal pancreatic cells do not, few findings have been published regarding the role of LHRH and LHRHR in pancreatic cancer ${ }^{15}, 16$. However, LHRH decapeptides were used to target cell surface receptors to deliver anticancer drugs specifically targeted to other cancer cells expressing their receptors. For example, Schally and coworkers utilized potent LHRH antagonists as targeting moieties for a variety of cancer drugs including Doxorubicin ${ }^{10}$. Studies on conjugates of [DLys $\left.{ }^{6}\right]$-LHRH-DOX and [DLys $\left.{ }^{6}\right]$-LHRH-2pyrrolino-DOX showed increased efficacy of doxorubicin as the LHRH analogue maintained its highly targeted binding affinity while the drug retained its cytotoxic effects on the tumor cells ${ }^{10}$. Hansel and co-workers ${ }^{1,2,6,17}$ showed that conjugates of lytic peptides and LHRH are very effective in destroying human breast and prostate cancer xenografts that express LHRH receptors.

Regular consumpution of certain fruits and vegetables has been reported to be effective in prevention of cancer ${ }^{18-21}$. Phytochemicals derived from such fruits and vegetables have 
significant antitumor activity in in vitro and in preclinical models. One such extensively studied phytochemical is curcumin (diferuloylmethane). It is present in an Asian spice called tumeric (Curcumin Longa) and has potent anti-proliferative and pro-apoptotic effects on cancer cells in vitro 22,23 , as well as in preclinical cancer models, inhibiting cell survival transcription factors such as nuclear transcription factor-kappa $\mathrm{B}(\mathrm{NF}-\mathrm{\kappa B})^{24-26}$. Because of its lack of toxicity, there is increasing interest in further studies with Curcumin. However, free Curcumin cannot be administered systemically because it is highly hydrophobic and not soluble in water. Nevertheless, it potentiated the effect of the chemotherapeutic agent, gemcitabine, when administered orally to an orthotopic model of pancreatic cancer in mice ${ }^{27}$. In the present study we conjugated [DLys ${ }^{6}$ ]-LHRH and Curcuimn and examined the efficacy of the conjugate ([DLys $\left.{ }^{6}\right]-\mathrm{LHRH}-\mathrm{Curcumin}$ ) against pancreatic cancer cells in vitro and in vivo. Our data show that, unlike Curcumin itself, the [DLys $\left.{ }^{6}\right]$-LHRH-Curcumin conjugate is soluble in water and can be administered intravenously. Treatment of pancreatic cancer cells in vitro and pancreatic cancer cell xenografts in nude mice with the [DLys ${ }^{6}$ ]LHRH-Curcumin conjugate is shown to prevent pancreatic cancer cell growth.

\section{Materials and Methods}

Pancreatic cancer cell lines MIAPaCa-2, BxPC-3, and Panc-1 were obtained from American Type Culture Collection (ATCC) VA, USA. All cell lines were cultured in DMEM supplemented with $10 \%$ FBS, 100 units $/ \mathrm{mL}$ penicillin, and $100 \mu \mathrm{g} / \mathrm{mL}$ streptomycin (Invitrogen, CA, USA)

\section{Confocal laser scanning microscopy}

Pancreatic cancer cells were grown on cover slips, fixed with $2 \%$ formaldehyde, washed with PBS, permeabilized with $0.1 \%$ Trion-X100 and incubated with $2 \%$ goat serum for one hour. The cells were then incubated with a primary antibody specific for LHRH receptor (GnRH-R Ab03, Lab Vision Corporation, Fremont, CA) overnight at $4{ }^{\circ} \mathrm{C}$, then washed with PBS and incubated with a secondary antibody conjugated with Alexa Fluor 488 (Molecular Probes, Eugene, OR) for one hour followed by three washings with PBS. Finally, cells were mounted with mounting medium from Molecular Probes (Carlsbad, CA) and images of LHRHR immunostained cells were acquired under an oil immersion objective (x40) with a confocal laser microscope (Zeiss Confocal LSM510, Carl Zeiss MicroImaging Inc. Thornwood, NY, USA) equipped with an argon-krypton laser.

\section{Flow cytometer analysis}

The ability of LHRHRmab to bind the cell surface of pancreatic cancer cells expressing LHRHR was determined as described previously ${ }^{28}$. Briefly, one million cells were collected and washed with PBS containing $1 \%$ FBS and subsequently incubated with $10 \mu \mathrm{g} / \mathrm{ml}$ LHRHRmab antibody on ice for $30 \mathrm{~min}$. Cells were washed twice with PBS containing 1\% FBS and further incubated with a secondary antibody, Alexa Fluor 488mab (Molecular probes, Eugene, OR) for $30 \mathrm{~min}$ on ice. Cells were washed twice and resuspended in $300 \mu \mathrm{ls}$ of PBS for analysis by flow cytometry. Ten thousand events were collected on the FASCcalibur flow cytometer and analyzed using cellquest software (Becton Dickinson). 
Isotype controls were prepared similarly except that an isotype IgG1 from Santa Cruz Biotechnology (Santa Cruz, CA) was used instead of the primary LHRH receptor antibody.

\section{Reverse Transcriptase - Polymerase Chain Reaction (RT-PCR)}

Total RNA was extracted using the TRIzol reagent (Invitrogen, Carlsbad, CA, USA), Firststrand, cDNA, was synthesized using High Capacity cDNA Reverse Transcription kit (ABI, Foster City, CA, USA) according to the manufacturer's protocol. PCR amplification was performed by using GenAmp PCR System 2400 (Perkin-Elmer Instruments, Shelton, CT, USA) for LHRH receptors, caspase-3, caspase- 9 and $\beta_{2}$-microglobulin ( $\beta_{2}$-m, internal control) with Taq Polymerase (Sigma Aldrich, St. Louis, MO, USA). The PCR conditions and primers were as described previously ${ }^{29}$.

\section{Design and Synthesis of [DLys $\left.{ }^{6}\right]-$ LHRH-Curcumin conjugate}

All chemicals were purchased from Sigma Chemical Co. (St. Louis, MO, USA) or Fisher Scientific (NJ, USA). Design scheme; A prototype embodiment employing a glutarate ester linkage to covalently link the two components of the conjugate was used. Glutarate ester linkages yield derivatives that are stable in aqueous solution, but will be readily hydrolyzed in the presence of an esterase to release the drug at the delivery site. The peptide [DLys ${ }^{6}$ ]LHRH was assembled using the general Fmoc chemistry using the amino acids described in the synthesis section. Once the peptide was assembled, a catalytic amount of $\mathrm{Pd}(0)$ was used to deprotect the primary amine at the D lysine in the presence of a nucleophile (morpholine) which mainly acts as a scavenger by capturing the carbocations generated. Sodium N, N-diethyldithiocarbamate in DMF was used in the washing step to aid in the removal of all of the palladium. Taking advantage of the well-established selective reactivity of the phenol group of Curcumin, reaction of glutaric anhydride with Curcumin in the presence of a mild base such as pyridine gave rise to the Curcumin glutarate ester derivative ${ }^{30}$. Coupling of this derivative to [DLys $\left.{ }^{6}\right]$-LHRH was done in solid-phase to give the [DLys ${ }^{6}$ ]-LHRH-Curcumin (Fig. 2A). The Curcumin should be readily released at the site of action causing apoptosis in tumor cells. Synthesis; Under dry conditions, a solution of Curcumin $(0.1 \mathrm{~g}, 0.271 \mathrm{mmol})$ in $1 \mathrm{~mL}$ of pyridine was stirred at room temperature for 30 $\mathrm{min}$. The solution was treated with glutaric anhydride salt $(0.028 \mathrm{~g}, 0.246 \mathrm{mmol})$ and stirred overnight at $60^{\circ} \mathrm{C}$. The solution was concentrated by rotary evaporation, dissolved in $\mathrm{CH}_{2} \mathrm{Cl}_{2}$, and washed with $5 \% \mathrm{HCL}$. The organic fraction was dried over $\mathrm{MgSO}_{4}$, and the solvent was removed by rotary evaporation. The solid product was dried in a desiccator for 8 $\mathrm{h}$ to give dry Curcumin glutarate ester. Yield, $106 \mathrm{mg}(90 \%),{ }^{1} \mathrm{H}$ NMR $(400 \mathrm{MHz}, \delta(\mathrm{ppm})$ in $\left.\mathrm{CDCl}_{3}\right): 7.61(\mathrm{~m}, 2 \mathrm{H}), 7.16(\mathrm{~m}, 5 \mathrm{H}), 6.94(\mathrm{~m}, 1 \mathrm{H}), 6.53(\mathrm{~m}, 2 \mathrm{H}) .5 .83(\mathrm{~m}, 2 \mathrm{H}), 3.95(\mathrm{~s}, 3 \mathrm{H})$, $3.87(\mathrm{~s}, 3 \mathrm{H}), 2.70(\mathrm{t}, 2 \mathrm{H}), 2.56(\mathrm{t}, 2 \mathrm{H}), 2.11(\mathrm{~m}, 2 \mathrm{H})$. ESI-MS $(\mathrm{M}+\mathrm{H})^{+}$calculated for $\mathrm{C}_{26} \mathrm{H}_{26} \mathrm{O}_{9} 483.1577$, found 483.1647. The [DLys ${ }^{6}$ ]-LHRH-Curcumin conjugate was then synthesized by Fmoc solid phase chemistry techniques. H-Rink Amide ChemMatrix resin $(0.52 \mathrm{mmol})$ was placed onto a column. The resin was then washed with DMF in continuous-flow mode using a pioneer Peptide Synthesizer. All couplings employed four equivalents of amino acid and PyAOP (and sometimes HOBT and TBTU), dissolved in 0.5 M DIEA in DMF at room temperature to a final concentration of $0.25 \mathrm{M}$. Coupling involved minimal preactivation times. The side chain-protected amino acid derivatives Fmoc-Gly$\mathrm{OH}$, Fmoc-Pro-OH, Fmoc-Arg(Pbf)-OH, Fmoc-Leu-OH, Fmoc-D-Lys(Alloc)-OH, Fmoc- 
Tyr(tBu)-OH, Fmoc-Ser(tBu)-OH, Fmoc-Trp(Boc)-OH, Fmoc-His(Trt)-OH, and Boc-

$\mathrm{Glu}(\mathrm{OtBu})-\mathrm{OH}$ were used. The Alloc protecting group was removed using $\mathrm{Pd}(0)$, followed by double-coupling of Curcumin glutarate ester. Intermediate products were washed between reactions with DMF. The Fmoc group was deprotected with 20\% piperidine in DMF for 5 min. Using a cocktail of TFA: phenol: water: TIPS (88:5:5:2) (15 mL), the peptide was cleaved from the resin, precipitated and dried under vacuum to give the crude peptide conjugate. [DLys ${ }^{6}$ ]-LHRH-Curcumin was purified by gel filtration using Sephadex

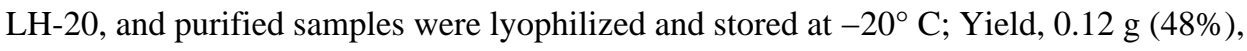
ESI-MS (M+Na) ${ }^{+}$, calculated for $\mathrm{C}_{85} \mathrm{H}_{108} \mathrm{~N}_{18} \mathrm{O}_{21} 1736.7936$, found 1739.79 (Fig. 2B). The mass spectrum of Curcumin glutarate ester is shown in supplementary Fig 1. S1.

\section{Proliferation assay}

The cell proliferation assay was done by a MTT (3-(4, 5-dimethylthiazol-2-yl)-2, 5diphenyltetrazolium bromide) assay as described previously ${ }^{23}$. In a competition assay, cells $\left(5,000\right.$ per well) were separately incubated in 96 well plates in triplicate with [DLys ${ }^{6}$ ]LHRH-Curcumin alone and [DLys $\left.{ }^{6}\right]$-LHRH free peptide and [DLys $\left.{ }^{6}\right]$-LHRH-Curcumin together, and incubated for $24 \mathrm{~h}$. The plates were then analyzed by the MTT method.

\section{Apoptosis Assay}

To determine the apoptotic effects of [DLys $\left.{ }^{6}\right]$-LHRH-Curcumin in pancreatic cancer cells, we used a Live/Dead assay kit (Molecular Probes, Eugene, OR) as per manufacturer's instructions as described previously ${ }^{28}$. Stained cells were mounted with mounting medium from Molecular Probes (Carlsbad, CA) and analyzed under a fluorescence microscope (Axioskop 40), Pictures were captured using Zeiss AxioCam HRc color CCD camera and Axiovision LE software (Carl Zeiss Inc., Jena, Germany). Apoptosis was confirmed by flow cytometry as described earlier ${ }^{31}$. Curcumin, [DLys $\left.{ }^{6}\right]$-LHRH-Curcumin and [DLys $\left.{ }^{6}\right]$-LHRH treated cells, at two concentrations after incubation for 24 hours were stained with FITCconjugatedAnnexin V. Ten thousand events were analyzed and \% positive cells evaluated using CellQuest Pro software (Becton Dickinson, San Jose, CA).

\section{Apo-ONE homogenous caspase- $3 / 7$ assay}

Pancreatic cancer cells were treated with free peptide [DLys ${ }^{6}$ ]-LHRH, or [DLys ${ }^{6}$ ]-LHRHCurcumin and the Apo-ONE homogenous caspase-3/7 kit (Promega, Madison, WI) assay was performed according to the manufacturer's protocol as described previously ${ }^{30}$.

\section{Western Blotting}

PARP cleavage and cleaved caspase- 3 were assayed by Western blotting of whole cell extracts using a monoclonal anti-PARP antibody and a polyclonal anti-caspase-3 antibody (Cell Signaling Technology, Cambridge, MA) and the ECL method (Amersham) according to the manufacturer's instructions. Cells grown in six well culture plates in duplicate were treated with $10 \mu \mathrm{M}$ of Curcumin, [DLys $\left.{ }^{6}\right]$-LHRH-Curcumin and [DLys $\left.{ }^{6}\right]$-LHRH for 24 hours and $50 \mu \mathrm{M}$ Staurosporine for 6 hours as a positive control. Culture plates were harvested by brief trypsinization. Both cells and culture supernatants (containing floating dead cells) were collected, centrifuged and washed with PBS. The pellet was resuspended in 
lysis buffer (125 mM Tris, pH 7.0, 15\% sucrose, 4\% SDS, 10 mM EDTA, 0.001\% bromophenol blue, $100 \mathrm{mM}$ dithiothreitol and a protease inhibitor. DNA was sheared by sonication and standard SDS-PAGE and Western blotting procedures were used to analyze the cell extracts. Nitrocellulose blots were probed with anti-PARP and anti-cleaved caspase-3. (Cell Signaling Technology, Cambridge, MA). Anti-GAPDH antibodies (Millipore, Billerica, MA) were used to detect the total protein.

\section{Animals}

Female nude mice (athymic Balb/c, 5 weeks old) obtained from a commercial vendor (Charles River Laboratories, Wilmington, MA) were housed in the standard mouse Plexiglas cages in a room maintained at constant temperature and humidity under a $12 \mathrm{~h}$ light and darkness cycle. Animals were fed irradiated pelleted chow (PicoLab Rodent Diet 20, Ren's Feed and Suppliers Ltd., Oakville, ON) with water ad libitum. The experimental protocol was reviewed and approved by the Institutional Animal Care and Use Committee at the Pennington Biomedical Research Center.

\section{Subcutaneous implantation of MIAPaCa-2 cells}

MIAPaCa-2 cells were harvested from subconfluent cultures after a brief exposure to $0.25 \%$ trypsin and $0.2 \%$ EDTA. Trypsinization was stopped by adding medium containing $10 \%$ FBS. The cells were washed once in serum-free medium and resuspended in PBS. Only suspensions consisting of single cells with $>90 \%$ viability were used for the injections. MIAPaCa- 2 cells $\left(1 \times 10^{6}\right)$ in $100 \mu \mathrm{L}$ PBS suspended in Matrigel $(0.1 \mathrm{mg})$ (Collaborative Biomedical Products Becton Dickinson Labware, Bedford, MA) were injected subcutaneously into the interscapular area using a 27-gauge needle.

\section{Experimental protocol}

On day 21, after tumor cell implantation, mice bearing tumors between $100-200 \mathrm{~mm}^{3}$, were randomized into the following treatment groups $(\mathrm{n}=8)$; Base line controls; Vehicle controls; $\left[\right.$ DLys $\left.^{6}\right]$-LHRH treated, and $\left[\right.$ DLys $\left.^{6}\right]$-LHRH-Curcumin treated. Treatments were made in $100 \mu \mathrm{L}$ PBS and were given intravenously by tail vein injections twice weekly for three weeks. The vehicle treated group received an equivalent amount of PBS. An additional control group was sacrificed prior to the beginning of treatment to obtain baseline data to measure whether the treatments caused tumor regression, or only a decreased rate of tumor growth. Tumor volumes were measured with calipers twice a week and body weights of mice were measured once a week. Tumor volumes were calculated by the formula: $\mathrm{V}\left(\mathrm{mm}^{3}\right)=($ length $\times$ width $) / 2$, in which width was the shortest measurement in millimeters. Mice were necropsied one week after the last treatment (day $28^{\text {th }}$ after the randomization and day 49 from the tumor cell implantation). Tumors were dissected, weighed, photographed and portions were fixed by immersion in 5\% neutral buffered formalin. The histology tissue samples were processed into paraffin blocks, and 5- $\mu \mathrm{m}$ sections were cut for hematoxylin and eosin staining (H\&E). These H\&E stained sections were examined for cellular characteristics, necrosis and inflammation in the tumors. Also, ovaries fixed and sectioned by the methods described above, were examined for follicle growth, ovulation and the presence of corpora leutea. In a separate experiment we compared 
tumor growth in Curcumin treated mice $(60 \mathrm{mg} / \mathrm{Kg}$ in $100 \mu \mathrm{L}$ of corn oil) and mice treated with an equivalent amount of corn oil alone. Treatments were administered by gavage. The time line of the randomization and treatments was similar to that described above.

\section{TUNEL assay}

Apoptosis in sections from paraffin-embedded tumors, untreated and treated were evaluated by the terminal deoxynucleotidyl transferase-mediated dUTP nick-end labeling (TUNEL) assay (Promega, Madison, WI) as per manufacturer's instructions. Finally, tumor sections were mounted with mounting medium from Molecular Probes (Carlsbad, CA) and images were acquired under an oil immersion objective $(x 40)$ with a confocal laser microscope (Zeiss Confocal LSM510, Carl Zeiss MicroImaging Inc. Thornwood, NY, USA) equipped with an argon-krypton laser.

\section{Statistical analysis}

Data are expressed as means \pm standard deviation/or standard error. Statistical analyses were done by using GraphPad Prism (software version 5.0. VA). Differences were determined by ANOVA and Student's $t$ test or, when appropriate. A $p$ value of $<0.05$ was considered significant.

\section{Results}

We used MIAPaCa-2 and Panc-1 cells, both of which exhibit mutations in K-ras, and BxPC-3 cells which exhibit wild type K-ras. All three cell lines, MIAPaCa-2, Panc-1 and BxPC-3 exhibit mutations in $\mathrm{p} 53^{32}$.

\section{Pancreatic cancer cells express LHRH receptors}

Confocal microscopic analysis (Fig. 1A) showed that all three pancreatic cancer cell lines, MIAPaCa-2, Panc-1 and BxPC-3, and the breast cancer cell line MDA-MB- 435S (positive control) expressed LHRHR on their surface. This result was further confirmed by flow cytometer analysis. Incubation of the pancreatic cancer cells with LHRHRmab revealed specific binding to LHRHR expressed on the cell membrane (Fig. 1B). The LHRHR gene was also expressed in all three pancreatic cancer cell lines (Fig. 1C).

\section{[DLys $\left.{ }^{6}\right]$-LHRH-Curcumin inhibits proliferation of pancreatic cancer cells}

[DLys $\left.{ }^{6}\right]$-LHRH-Curcumin inhibited pancreatic cancer cell proliferation in a dose dependent manner in all three pancreatic cancer cell lines as shown in Fig. 3(A-C). The [DLys ${ }^{6}$ ]LHRH (free peptide) was significantly less effective on pancreatic cancer cell proliferation than the $\left[\mathrm{DLys}^{6}\right]$-LHRH-Curcumin conjugate. The $\mathrm{IC}_{50}$ for $\left[\mathrm{DLys}{ }^{6}\right]$-LHRH-Curcumin varied for different pancreatic cancer cell lines; for MIAPaCa-2, it was $3 \mu \mathrm{M} \pm 0.42$, for Panc-1 $10 \mu \mathrm{M} \pm 0.63$ and for BxPC-3 $2.5 \mu \mathrm{M} \pm 0.67$. We compared the activity of [DLys ${ }^{6}$ ]LHRH-Curcumin with Curcumin at different equimolar concentrations by MTT assay (Supplementary Fig 1. S2). The activity of the [DLys $\left.{ }^{6}\right]$-LHRH-Curcumin was equivalent to free Curcumin indicating that Curcumin in [DLys $\left.{ }^{6}\right]$-LHRH-Curcumin is as active as free Curcumin. When pancreatic cancer cells were co-incubated with [DLys $\left.{ }^{6}\right]$-LHRH (free peptide) and $\left[\mathrm{DLys}^{6}\right]$-LHRH-Curcumin, the cytotoxic effect of [DLys $\left.{ }^{6}\right]$-LHRH-Curcumin 
was significantly lower (increased $\%$ cell viability) than that of [DLys $\left.{ }^{6}\right]$-LHRH-Curcumin alone, indicating that the $\left[\mathrm{DLys}^{6}\right]$-LHRH-Curcumin conjugate and the free peptide compete for binding sites on the pancreatic cancer cell membrane (Fig. 3D).

\section{[DLys $\left.{ }^{6}\right]$-LHRH-Curcumin induces apoptosis in pancreatic cancer cells}

A Live/Dead assay was conducted to determine whether treatment with [DLys $\left.{ }^{6}\right]$-LHRHCurcumin induces apoptosis in pancreatic cancer cells. The Live/Dead assay used determines intracellular esterase activity and plasma membrane integrity. This assay utilizes calcein, a polyanionic, green fluorescent dye that is retained within live cells, and a red fluorescent dye, ethidium bromide homodimer, a dye that can enter cells through damaged membranes and bind to nucleic acids, but is excluded by the intact plasma membranes of live cells ${ }^{28}$. Treatment of MIAPaCa-2 cells for $24 \mathrm{~h}$ with $10 \mu \mathrm{M}$ of [DLys ${ }^{6}$ ]-LHRH alone resulted in $12 \% \pm 1.5$ apoptosis while treatment with [DLys ${ }^{6}$ ]-LHRH-Curcumin resulted in $55 \% \pm 1.05$ apoptosis $(\mathrm{p}<0.05)$. Staining of the cells with FITC-conjugated Annexin V showed dose responsive induction of apoptosis to Curcumin, and [DLys $\left.{ }^{6}\right]$-LHRH-Curcumin (Fig. 4B). Flow cytometry was carried out at two concentrations of [DLys $\left.{ }^{6}\right]-\mathrm{LHRH}$, [DLys ${ }^{6}$ ]-LHRH-Curcumin and free Curcumin. The percentage of apoptosis positive cells for [DLys ${ }^{6}$ ]-LHRH, [DLys ${ }^{6}$ ]-LHRH-Curcumin and free Curcumin at $5 \mu \mathrm{M}$ of concentartion was, $10 \% \pm 2.0,41 \% \pm 5.5$, and $30 \% \pm 6.1$ and at $10 \mu \mathrm{M}$ of concentration was $19 \% \pm 4.0$, $57 \% \pm 3.1$ and $66 \% \pm 5.0$. There wasn't any significant difference between [DLys ${ }^{6}$ ]-LHRHCurcumin and Curcumin alone stained cells. The result was in agreement with the previous result in as described above (Supplementary Fig 1. S2). Fig. 4B clearly indicates that the $\left[\right.$ DLys $\left.^{6}\right]$-LHRH-Curcumin conjugate significantly increased apoptosis when compared to $\left[\right.$ DLys $\left.^{6}\right]$-LHRH alone. The activity of $\left[\mathrm{DLys}^{6}\right]$-LHRH-Curcumin is equivalent to Curcumin at equimolar concentrations. Further, we looked at the activation of polyadenosine-5'diphosphate-ribose-polymerase (PARP), an enzyme involved in DNA damage and repair mechanism. During apoptosis, PARP is cleaved by a protease caspase- 3 an, important downstream apoptotic caspase. Western blot analysis using anti-PARP antibody and anticleaved caspase- 3 antibody clearly demonstrated that treatment of MIAPaCa- 2 cells with Curcumin and [DLys ${ }^{6}$ ]-LHRH-Curcumin activated PARP and caspase- 3 cleavage (active form) (Fig. 4C). In addition, treatment of MIAPaCa-2 cells with [DLys ${ }^{6}$ ]-LHRH-Curcumin significantly increased the activation of caspase-3/7 compared to [DLys ${ }^{6}$ ]-LHRH alone ( $\mathrm{p}=$ 0.007) (Fig. 4D). There was an increase in caspase-3 and caspase- 9 mRNA with treatment of LHRH-Curcumin conjugate (Fig. 4E) which has also been observed by other groups ${ }^{29,} 33$ showing that LHRH-conjugates increase the mRNA of caspases.

\section{[DLys $\left.{ }^{6}\right]$-LHRH-Curcumin prevents growth of pancreatic cancer cell xenografts in nude mice}

A schematic representation of the experimental protocol is shown in supplementary Fig. S3. A time -related increase in tumor volume was observed in the Vehicle-treated group and in the [DLys $\left.{ }^{6}\right]$-LHRH treated group (Fig. 5A), while the tumor volume in the group treated with $\left[\right.$ DLys $\left.^{6}\right]$-LHRH-Curcumin was maintained at the baseline level $(\mathrm{p}>0.05)$. As shown in (Fig. 5B) tumor volumes at necropsy on day 49 were significantly $(\mathrm{p}<0.01)$ reduced in the [DLys ${ }^{6}$ ]-LHRH-Curcumin treated group compared to the vehicle treated controls and the $\left[\right.$ DLys $\left.^{6}\right]$-LHRH treated group. As indicated in (Fig. 5C) tumor weights at necropsy were 
significantly $(\mathrm{p}<0.01)$ decreased to baseline levels in the $\left[\mathrm{DLys}^{6}\right]$-LHRH-Curcumin treated group. The reduced size of tumors from [DLys $\left.{ }^{6}\right]$-LHRH-Curcumin treated mice is evident in Fig. 5D. In a separate experiment, we examined the effect of Curcumin $(60 \mathrm{mg} / \mathrm{Kg})$, given twice a week in corn oil by gavage, on tumor volume and tumor weight as compared to a control group given an equivalent amount of corn oil. We found no significant difference in the mean tumor volume or mean tumor weight between Curcumin and corn oil treated mice. (Supplementary Fig. 2 S 4A-4C).

No histological alterations were observed in the sub-scapular and axillary lymph nodes, pancreases, liver and lungs in the treated groups (data not shown). On histopathologic examination, tumor sections from [DLys $\left.{ }^{6}\right]$-LHRH-Curcumin treated mice showed areas of necrosis (Fig. 6A). Enhanced apoptosis in the tumors of treated mice was seen by TUNEL assay (Fig. 6B). Body weights monitored as an indicator of toxicity of [DLys $\left.{ }^{6}\right]$-LHRHCurcumin, were unaffected by treatment (Fig. 6C). The ovaries from untreated and treated mice consisted of many normal follicles in various developmental stages and multiple corpora lutea (Fig. 6D). No side effects in the [DLys $\left.{ }^{6}\right]$-LHRH-Curcumin treated mice were observed.

\section{Discussion}

Uncontrolled cell growth and resistance to apoptosis are the major defects in pancreatic cancer. Our in vitro data showed that MIAPaCa-2, BxPC-3 and Panc-1 pancreatic cancer cells express LHRH receptors and that [DLys $\left.{ }^{6}\right]$-LHRH-Curcumin significantly inhibits pancreatic cancer cell proliferation (Fig. 3A). We also observed a significant decrease in the cytotoxicity of [DLys $\left.{ }^{6}\right]$-LHRH-Curcumin when it was co-incubated with [DLys $\left.{ }^{6}\right]-\mathrm{LHRH}$ (free peptide) (Fig. 3B), indicating that [DLys $\left.{ }^{6}\right]$-LHRH -Curcumin and the free peptide compete for binding sites on the pancreatic cancer cell membranes that express LHRH receptors. Many anti-cancer drugs induce cell death by activation of intracellular apoptotic signals. Although the process of apoptosis induction is complex and involves many steps, the main event in the process is the leakage of cytochrome $\mathrm{c}$ from mitochondria to the cytoplasm, leading to activation of caspase executors of apoptosis ${ }^{30}$. We found that [DLys ${ }^{6}$ ]-LHRH-Curcumin induces apoptosis in pancreatic cancer cells via activation of caspase-3 (Fig. 4C-D). In in vitro assays, the activity of [DLys $\left.{ }^{6}\right]$-LHRH-Curcumin is equivalent to Curcumin at equimolar concentrations (supplementary Fig. S2, Fig. 4B and Fig. 4C). However [DLys $\left.{ }^{6}\right]$-LHRH-Curcumin is soluble in autoclaved water, and can therefore be administered systemically. We also observed some apoptotic effects of $\left[\right.$ DLys $\left.^{6}\right]$-LHRH alone in pancreatic cancer cells, a result that is consistent with reports that LHRH alone has a minimal apoptotic effect in ovarian and endometrial cancers ${ }^{34-36}$. In our synthesis of [DLys $\left.{ }^{6}\right]-$ LHRH- Curcumin, we introduced an ester bond between the two components of the conjugate. It is known that such a bond is hydrolyzed by cellular esterases within the cell, leaving the drug free to act at the cellular level ${ }^{37,38}$. Thus; Curcumin is readily released to the site of action, causing apoptosis in tumor cells. The binding affinity of the LHRH analog ([DLys $\left.\left.{ }^{6}\right]-\mathrm{LHRH}\right)$ to its receptors remains unchanged. It was previously shown that LHRH can be modified at the epsilon amino side chain of its DLys ${ }^{6}$ moiety by large molecules without loss of its ability to bind to LHRH receptors ${ }^{10}$. 
In an in vivo study, we showed that intravenous injections of [DLys $\left.{ }^{6}\right]$-LHRH-Curcumin prevented the growth of MIAPaCa-2 cancer cell xenografts in athymic mice (Fig. 5A-D). The mean volume and mean weight of the tumors of [DLys $\left.{ }^{6}\right]$-LHRH-Curcumin treated mice were significantly $(\mathrm{p}=0.001)$ reduced from the volumes and weights of vehicle treated control and $\left[\mathrm{DLys}^{6}\right]$-LHRH treated mice. The mean tumor weight of [DLys $\left.{ }^{6}\right]-\mathrm{LHRH}-$ Curcumin treated mice did not differ from the mean weight of the tumors removed from mice before the beginning of the treatment (baseline controls), indicating a ceasation of growth of the tumors of the treated mice. However, it was also noted that complete tumor regression occurred in 2 of the 8 mice treated with [DLys ${ }^{6}$ ]-LHRH-Curcumin, indicating that this drug can cause tumor regression. [DLys $\left.{ }^{6}\right]$-LHRH-Curcumin treatment acts by causing apoptosis, as indicated by the tunnel assay and the histological observations of the treated tumors (Fig. 6A). In an additional in vivo experiment, we observed no significant differences in the mean tumor volumes and mean tumor weights between nude mice treated by gavage with $60 \mathrm{mg} / \mathrm{kg}$ of Curcumin and mice treated with an equivalent amount of corn oil $(p=0.10)$ (Supplementary Fig. 2S4).

Our results are in general agreement with those of previous studies showing that pancreatic cancers and other solid tumors express LHRH receptors ${ }^{15,39,40}$. Various cancer cells that express LHRH receptors (breast, prostate and ovarian) have been targeted by LHRH conjugated to lytic peptides $1,2,41$, doxorubicin ${ }^{10}$ or eukaryotic translation initiation factor (elF4E) ${ }^{42}$. Previous studies also indicated that Curcumin and its analogs may enhance apoptosis in cancer cells ${ }^{27}, 43-46$. No side effects were seen in mice given a dose of [DLys ${ }^{6}$ ]LHRH-Curcumin $(60 \mathrm{mg} / \mathrm{kg})$ twice a week. Ovarian cells are reported to express a limited number of LHRH receptors ${ }^{33,47}$ but we did not detect any damage to the ovaries of $\left[\right.$ DLys $\left.^{6}\right]$-LHRH and [DLys $\left.{ }^{6}\right]$-LHRH-Curcumin treated groups. It was also shown that the function of the pituitary gonadotrophs was completely recovered within in two weeks after treatment with a targeted cytotoxic analog of $\mathrm{LHRH}^{48}$.

The clinical use of Curcumin is limited because it cannot be administered systemically and has poor bioavailability and rapid metabolism on oral ingestion. This requires very high oral doses of Curcumin to achieve activity $27,49,50$. Our experiments are the first to demonstrate that a hormone domain comprising [DLys ${ }^{6}$ ]-LHRH conjugated to a phytochemical, Curcumin ([DLys $\left.{ }^{6}\right]$-LHRH-Curcumin) has the ability to target and inhibit the growth of human pancreatic tumors. Unlike Curcumin itself, [DLys ${ }^{6}$ ]-LHRH-Curcumin is readily soluble in water, enabling its systemic administration and its targeting to LHRH expressing cancer cells. Further studies are needed to analyze the pharmacokinetics of the [DLys ${ }^{6}$ ]LHRH-Curcumin and to test its effects over a range of doses. Because of its lack of toxicity, its solubility and its ability to target and inhibit pancreatic tumor growth, Curcumin conjugated to LHRH or an analog may prove useful in the treatment of pancreatic cancer.

\section{Supplementary Material}

Refer to Web version on PubMed Central for supplementary material. 


\section{Acknowledgments}

This work was supported in part by the Hansel/Downey Research Fund, the Pennington Biomedical Research Foundation and by Louisiana State University, LA.

We thank, Qingxia Wang, for technical support and David Burk for assistance with fluorescence microscopy. The Bioimaging Core at Pennington Biomedical Research Center is supported, in part by COBRE (NIH P20RR021945) and CNRU (NIH IP30-DK072476) and the Pennington Biomedical Research Foundation.

\section{References}

1. Hansel W, Enright F, Leuschner C. Destruction of breast cancers and their metastases by lytic peptide conjugates in vitro and in vivo. Mol Cell Endocrinol. 2007; 260-262:183-9.

2. Hansel W, Leuschner C, Enright F. Conjugates of lytic peptides and LHRH or betaCG target and cause necrosis of prostate cancers and metastases. Mol Cell Endocrinol. 2007; 269:26-33. [PubMed: 17382461]

3. Jemal A, Siegel R, Ward E, Hao Y, Xu J, Thun MJ. Cancer statistics, 2009. CA Cancer J Clin. 2009; 59:225-49. [PubMed: 19474385]

4. Discher DE, Eisenberg A. Polymer vesicles. Science. 2002; 297:967-73. [PubMed: 12169723]

5. Torchilin VP. PEG-based micelles as carriers of contrast agents for different imaging modalities. Adv Drug Deliv Rev. 2002; 54:235-52. [PubMed: 11897148]

6. Leuschner C, Hansel W. Membrane disrupting lytic peptides for cancer treatments. Curr Pharm Des. 2004; 10:2299-310. [PubMed: 15279610]

7. David A, Kopeckova P, Minko T, Rubinstein A, Kopecek J. Design of a multivalent galactoside ligand for selective targeting of HPMA copolymer-doxorubicin conjugates to human colon cancer cells. Eur J Cancer. 2004; 40:148-57. [PubMed: 14687799]

8. Wirth M, Gerhardt K, Wurm C, Gabor F. Lectin-mediated drug delivery: influence of mucin on cytoadhesion of plant lectins in vitro. J Control Release. 2002; 79:183-91. [PubMed: 11853930]

9. Mao W, Luis E, Ross S, Silva J, Tan C, Crowley C, Chui C, Franz G, Senter P, Koeppen H, Polakis $\mathrm{P}$. EphB2 as a therapeutic antibody drug target for the treatment of colorectal cancer. Cancer Res. 2004; 64:781-8. [PubMed: 14871799]

10. Schally AV, Nagy A. Cancer chemotherapy based on targeting of cytotoxic peptide conjugates to their receptors on tumors. Eur J Endocrinol. 1999; 141:1-14. [PubMed: 10407215]

11. Grundker C, Gunthert AR, Westphalen S, Emons G. Biology of the gonadotropin-releasing hormone system in gynecological cancers. Eur J Endocrinol. 2002; 146:1-14. [PubMed: 11751060]

12. Fekete M, Wittliff JL, Schally AV. Characteristics and distribution of receptors for [D-TRP6]luteinizing hormone-releasing hormone, somatostatin, epidermal growth factor, and sex steroids in 500 biopsy samples of human breast cancer. J Clin Lab Anal. 1989; 3:137-47. [PubMed: 2569034]

13. Srkalovic G, Schally AV, Wittliff JL, Day TG Jr, Jenison EL. Presence and characteristics of receptors for [D-Trp6]luteinizing hormone releasing hormone and epidermal growth factor in human ovarian cancer. Int J Oncol. 1998; 12:489-98. [PubMed: 9472084]

14. Emons G, Ortmann O, Schulz KD, Schally AV. Growth-inhibitory actions of analogues of luteinizing hormone releasing hormone on tumor cells. Trends Endocrinol Metab. 1997; 8:355-62. [PubMed: 18406825]

15. Liebow C, Lee MT, Kamer AR, Schally AV. Regulation of luteinizing hormone-releasing hormone receptor binding by heterologous and autologous receptor-stimulated tyrosine phosphorylation. Proc Natl Acad Sci U S A. 1991; 88:2244-8. [PubMed: 1672452]

16. Friess H, Kleeff J, Korc M, Buchler MW. Molecular aspects of pancreatic cancer and future perspectives. Dig Surg. 1999; 16:281-90. [PubMed: 10449972]

17. Leuschner C, Hansel W. Targeting breast and prostate cancers through their hormone receptors. Biol Reprod. 2005; 73:860-5. [PubMed: 16033998] 
18. Adams LS, Phung S, Yee N, Seeram NP, Li L, Chen S. Blueberry phytochemicals inhibit growth and metastatic potential of MDA-MB-231 breast cancer cells through modulation of the phosphatidylinositol 3-kinase pathway. Cancer Res. 70:3594-605. [PubMed: 20388778]

19. Adams LS, Zhang Y, Seeram NP, Heber D, Chen S. Pomegranate ellagitannin-derived compounds exhibit antiproliferative and antiaromatase activity in breast cancer cells in vitro. Cancer Prev Res (Phila Pa). 3:108-13.

20. Henning SM, Seeram NP, Zhang Y, Li L, Gao K, Lee RP, Wang DC, Zerlin A, Karp H, Thames G, Kotlerman J, Li Z, et al. Strawberry consumption is associated with increased antioxidant capacity in serum. J Med Food. 13:116-22. [PubMed: 20136444]

21. Ray RB, Raychoudhuri A, Steele R, Nerurkar P. Bitter melon (Momordica charantia) extract inhibits breast cancer cell proliferation by modulating cell cycle regulatory genes and promotes apoptosis. Cancer Res. 70:1925-31. [PubMed: 20179194]

22. Kuo ML, Huang TS, Lin JK. Curcumin, an antioxidant and anti-tumor promoter, induces apoptosis in human leukemia cells. Biochim Biophys Acta. 1996; 1317:95-100. [PubMed: 8950193]

23. Aggarwal S, Takada Y, Singh S, Myers JN, Aggarwal BB. Inhibition of growth and survival of human head and neck squamous cell carcinoma cells by curcumin via modulation of nuclear factor-kappaB signaling. Int J Cancer. 2004; 111:679-92. [PubMed: 15252836]

24. Huang MT, Lou YR, Xie JG, Ma W, Lu YP, Yen P, Zhu BT, Newmark H, Ho CT. Effect of dietary curcumin and dibenzoylmethane on formation of 7,12-dimethylbenz[a]anthracene-induced mammary tumors and lymphomas/leukemias in Sencar mice. Carcinogenesis. 1998; 19:1697-700. [PubMed: 9771944]

25. Kim JM, Araki S, Kim DJ, Park CB, Takasuka N, Baba-Toriyama H, Ota T, Nir Z, Khachik F, Shimidzu N, Tanaka Y, Osawa T, et al. Chemopreventive effects of carotenoids and curcumins on mouse colon carcinogenesis after 1,2-dimethylhydrazine initiation. Carcinogenesis. 1998; 19:81-5. [PubMed: 9472697]

26. Aggarwal S, Ichikawa H, Takada Y, Sandur SK, Shishodia S, Aggarwal BB. Curcumin (diferuloylmethane) down-regulates expression of cell proliferation and antiapoptotic and metastatic gene products through suppression of IkappaBalpha kinase and Akt activation. Mol Pharmacol. 2006; 69:195-206. [PubMed: 16219905]

27. Kunnumakkara AB, Guha S, Krishnan S, Diagaradjane P, Gelovani J, Aggarwal BB. Curcumin potentiates antitumor activity of gemcitabine in an orthotopic model of pancreatic cancer through suppression of proliferation, angiogenesis, and inhibition of nuclear factor-kappaB-regulated gene products. Cancer Res. 2007; 67:3853-61. [PubMed: 17440100]

28. Aggarwal S, Takada Y, Mhashilkar AM, Sieger K, Chada S, Aggarwal BB. Melanoma differentiation-associated gene-7/IL-24 gene enhances NF-kappa B activation and suppresses apoptosis induced by TNF. J Immunol. 2004; 173:4368-76. [PubMed: 15383566]

29. Dharap SS, Minko T. Targeted proapoptotic LHRH-BH3 peptide. Pharm Res. 2003; 20:889-96. [PubMed: 12817893]

30. Ndinguri MW, Solipuram R, Gambrell RP, Aggarwal S, Hammer RP. Peptide Targeting of Platinum Anti-Cancer Drugs. Bioconjug Chem. 2009

31. Syng-Ai C, Kumari AL, Khar A. Effect of curcumin on normal and tumor cells: role of glutathione and bcl-2. Mol Cancer Ther. 2004; 3:1101-8. [PubMed: 15367704]

32. Sipos B, Moser S, Kalthoff H, Torok V, Lohr M, Kloppel G. A comprehensive characterization of pancreatic ductal carcinoma cell lines: towards the establishment of an in vitro research platform. Virchows Arch. 2003; 442:444-52. [PubMed: 12692724]

33. Dharap SS, Wang Y, Chandna P, Khandare JJ, Qiu B, Gunaseelan S, Sinko PJ, Stein S, Farmanfarmaian A, Minko T. Tumor-specific targeting of an anticancer drug delivery system by LHRH peptide. Proc Natl Acad Sci U S A. 2005; 102:12962-7. [PubMed: 16123131]

34. Imai A, Horibe S, Takagi A, Ohno T, Tamaya T. Frequent expression of Fas in gonadotropinreleasing hormone receptor-bearing tumors. Eur J Obstet Gynecol Reprod Biol. 1997; 74:73-8. [PubMed: 9243207]

35. Imai A, Takagi A, Horibe S, Takagi H, Tamaya T. Fas and Fas ligand system may mediate antiproliferative activity of gonadotropin-releasing hormone receptor in endometrial cancer cells. Int J Oncol. 1998; 13:97-100. [PubMed: 9625809] 
36. Imai A, Takagi A, Horibe S, Takagi H, Tamaya T. Evidence for tight coupling of gonadotropinreleasing hormone receptor to stimulated Fas ligand expression in reproductive tract tumors: possible mechanism for hormonal control of apoptotic cell death. J Clin Endocrinol Metab. 1998; 83:427-31. [PubMed: 9467552]

37. Greenwald RB, Zhao H, Reddy P. Synthesis, isolation, and characterization of 2'-paclitaxel glycinate: an application of the Bsmoc protecting group. J Org Chem. 2003; 68:4894-6. [PubMed: 12790596]

38. Khandare JJ, Chandna P, Wang Y, Pozharov VP, Minko T. Novel polymeric prodrug with multivalent components for cancer therapy. J Pharmacol Exp Ther. 2006; 317:929-37. [PubMed: 16469865]

39. Szende B, Srkalovic G, Schally AV, Lapis K, Groot K. Inhibitory effects of analogs of luteinizing hormone-releasing hormone and somatostatin on pancreatic cancers in hamsters. Events that accompany tumor regression. Cancer. 1990; 65:2279-90. [PubMed: 1971771]

40. Lee MT, Liebow C, Kamer AR, Schally AV. Effects of epidermal growth factor and analogues of luteinizing hormone-releasing hormone and somatostatin on phosphorylation and dephosphorylation of tyrosine residues of specific protein substrates in various tumors. Proc Natl Acad Sci U S A. 1991; 88:1656-60. [PubMed: 1672042]

41. Hansel W, Leuschner C, Gawronska B, Enright F. Targeted destruction of prostate cancer cells and xenografts by lytic peptide-betaLH conjugates. Reprod Biol. 2001; 1:20-32. [PubMed: 14666172]

42. Ko SY, Guo H, Barengo N, Naora H. Inhibition of ovarian cancer growth by a tumor-targeting peptide that binds eukaryotic translation initiation factor 4E. Clin Cancer Res. 2009; 15:4336-47. [PubMed: 19458052]

43. Aggarwal BB, Shishodia S, Takada Y, Banerjee S, Newman RA, Bueso-Ramos CE, Price JE. Curcumin suppresses the paclitaxel-induced nuclear factor-kappaB pathway in breast cancer cells and inhibits lung metastasis of human breast cancer in nude mice. Clin Cancer Res. 2005; 11:7490-8. [PubMed: 16243823]

44. Chauhan DP. Chemotherapeutic potential of curcumin for colorectal cancer. Curr Pharm Des. 2002; 8:1695-706. [PubMed: 12171541]

45. Ali S, Ahmad A, Banerjee S, Padhye S, Dominiak K, Schaffert JM, Wang Z, Philip PA, Sarkar FH. Gemcitabine sensitivity can be induced in pancreatic cancer cells through modulation of miR-200 and miR-21 expression by curcumin or its analogue CDF. Cancer Res. 70:3606-17. [PubMed: 20388782]

46. Subramaniam D, May R, Sureban SM, Lee KB, George R, Kuppusamy P, Ramanujam RP, Hideg K, Dieckgraefe BK, Houchen CW, Anant S. Diphenyl difluoroketone: a curcumin derivative with potent in vivo anticancer activity. Cancer Res. 2008; 68:1962-9. [PubMed: 18339878]

47. Furui T, Imai A, Tamaya T. Intratumoral level of gonadotropin-releasing hormone in ovarian and endometrial cancers. Oncol Rep. 2002; 9:349-52. [PubMed: 11836606]

48. Kovacs M, Schally AV, Nagy A, Koppan M, Groot K. Recovery of pituitary function after treatment with a targeted cytotoxic analog of luteinizing hormone-releasing hormone. Proc Natl Acad Sci U S A. 1997; 94:1420-5. [PubMed: 9037068]

49. Cheng AL, Hsu CH, Lin JK, Hsu MM, Ho YF, Shen TS, Ko JY, Lin JT, Lin BR, Ming-Shiang W, $\mathrm{Yu} \mathrm{HS}$, Jee SH, et al. Phase I clinical trial of curcumin, a chemopreventive agent, in patients with high-risk or pre-malignant lesions. Anticancer Res. 2001; 21:2895-900. [PubMed: 11712783]

50. Dhillon N, Aggarwal BB, Newman RA, Wolff RA, Kunnumakkara AB, Abbruzzese JL, Ng CS, Badmaev V, Kurzrock R. Phase II trial of curcumin in patients with advanced pancreatic cancer. Clin Cancer Res. 2008; 14:4491-9. [PubMed: 18628464] 
A.

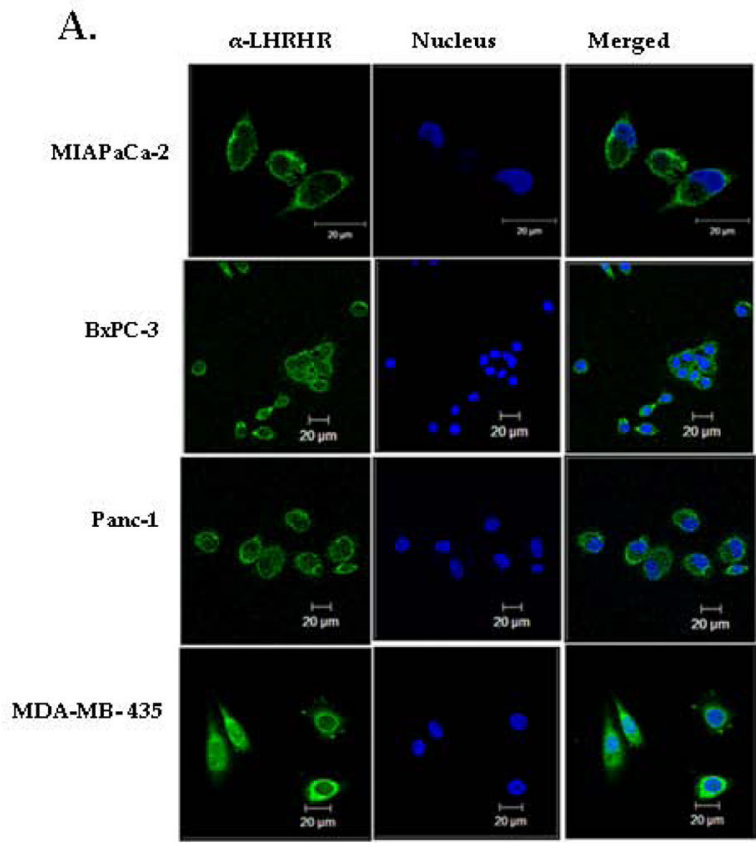

B.

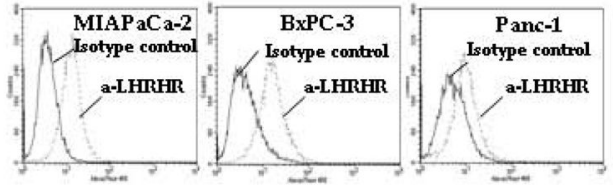

C.

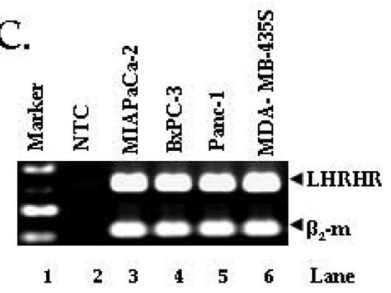

Figure 1. Pancreatic cancer cells over-express LHRH receptors (LHRHR)

A, Visualization of LHRHR by confocal microscopy. Pancreatic cancer cell lines MIAPaCa-2, BxPC-3 and Panc-1, were analyzed for the localization of LHRHR by immunocytochemistry. MDA-MB-435, breast cancer cells were used as a positive control. Green stain: Localization of LHRHR; Blue Stain: Localization of nucleus. B, Cell surface expression of LHRHR by flow cytometry analysis. One million cells were harvested and Ab-labelled for expression of LHRHR (dotted lines) and Isotype control (Solid line). Cells were incubated with mouse anti-LHRHR mabs, followed by FITC-conjugated goat antimouse mab. Figure represents three independent experiments. C, LHRH receptor gene expression in pancreatic cancer cell lines. RT-PCR using LHRHR and beta-2 microglobulion $\left(\left(\beta_{2}-\mathrm{m}\right)\right.$ specific primers which amplified $319 \mathrm{bp}$ and $114 \mathrm{bp}$ amplicons. Lanes 1, 2, 3, 4, 5, 6 represent 100 bp marker, no target control (NTC), MIAPaCa-2, BxPC-3, Panc-1, (pancreatic cancer cells), and MDA-MB-435 (breast cancer cells) respectively. Top panel shows significant amplification of LHRHR in MIAPaCa-2, BxPC3, Panc-1 and MDA-MB-435S cells (positive control) whereas the NTC shows no amplification. Bottom panel shows the expression of $\beta_{2}-\mathrm{m}$, (house keeping gene) in all the cell lines except NTC (negative control). Figure represents three independent experiments. 
A.

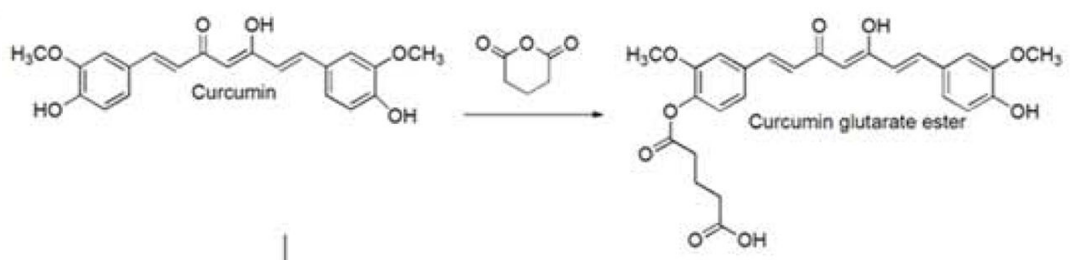

(A) PYAOP.

Glu(OtBu)-His(Trt)-Trp(Boc)-Ser(tBu)-Tyr(tBu)-DLys-Leu-Arg(Pbf)-Pro-Gly(DLys6)-LHRH

(B) Cocktail (TFA-Tips- $\mathrm{H}_{2} \mathrm{O}$-Phenol)

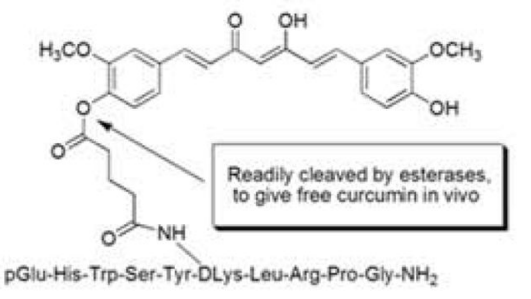

[DLys $s^{6}$ ]-L HRH -Curcumin

B.

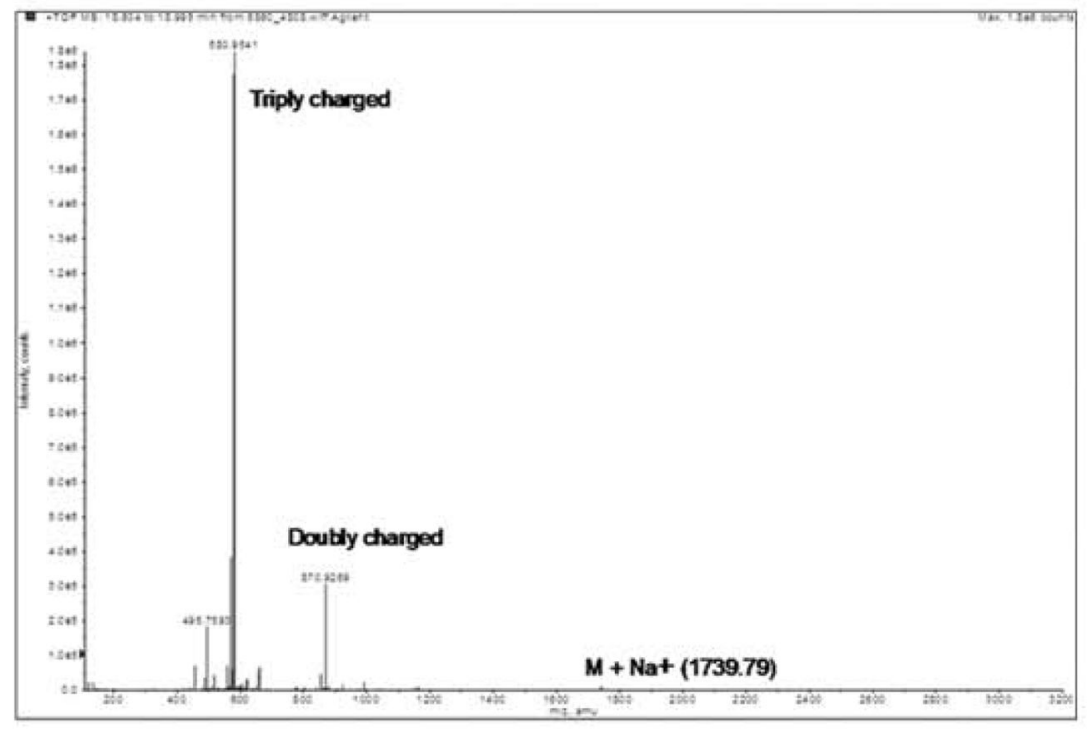

Figure 2.

A, Molecular structure and synthesis of [DLys $\left.{ }^{6}\right]-$ LHRH-Curcumin conjugate. The Curcumin is linked to the [DLys ${ }^{6}$ ]-LHRH through the e-amino group of the DLys ${ }^{6}$ moiety. The [DLys $\left.{ }^{6}\right]$-LHRH-Curcumin analog has an ester linkage to the Curcumin phenol group that is readily be cleaved by esterases, leading to release of free Curcumin at the site of conjugate binding. B, Mass spectrophotometer analysis of [DLys ${ }^{6}$ ]-LHRH-Curcumin. ESI-MS (M+Na) ${ }^{+}$, calculated for $\mathrm{C}_{85} \mathrm{H}_{108} \mathrm{~N}_{18} \mathrm{O}_{21}$ 1736.7936; found 1739.79 .

Int J Cancer. Author manuscript; available in PMC 2014 June 09. 

A.
B.
C.

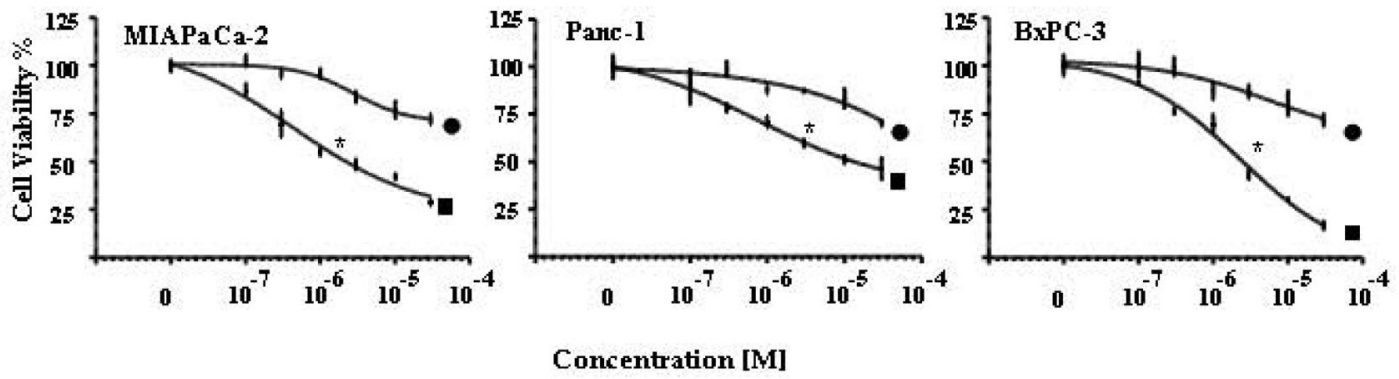

D.

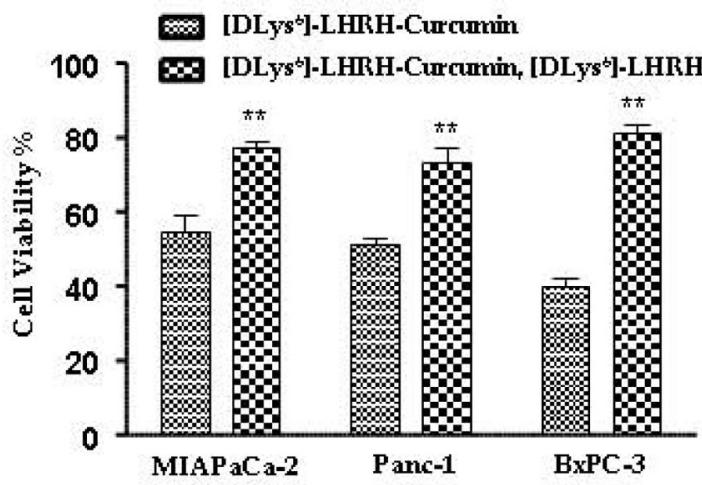

Figure 3.

A-C, Effects of [DLys ${ }^{6}$ ]-LHRH-Curcumin on pancreatic cancer cell proliferation.

MIAPaCa-2, Panc-1 and BxPC-3 cells (5000/well) were incubated in the absence or presence of increasing concentrations of [DLys ${ }^{6}$ ]-LHRH-Curcumin and [DLys ${ }^{6}$ ]-LHRH for $48 \mathrm{~h}$ and the number of viable cells examined by MTT. All points are means \pm S.D. of triplicate wells of three independent experiments. [DLys ${ }^{6}$ ]-LHRH-Curcumin decreased cell viability compared to $\left[\mathrm{DLys}^{6}\right]-\mathrm{LHRH}$ in each cell line $(* \mathrm{p}=0.012,0.033$, and 0.021 for MIAPaCa-2, Panc- 1 and BxPC-3 cells, respectively at $3 \mu \mathrm{M}$ and is statistically significant $(\mathrm{P}<0.05)$. D, The effect of co-incubation of [DLys $\left.{ }^{6}\right]$-LHRH-Curcumin and free [DLys $\left.{ }^{6}\right]$-LHRH on pancreatic cancer cell cytotoxicity. Pancreatic cancer cells, MIAPaCa-2, Panc-1 and BxPC-3 (5000 cells/well) were co-incubated with $10 \mu \mathrm{M}\left[\right.$ DLys $^{6}$ ]-LHRH-Curcumin and $10 \mu \mathrm{M}$ [DLys $\left.{ }^{6}\right]$-LHRH for $24 \mathrm{~h}$. The co-incubation of [DLys $\left.{ }^{6}\right]$-LHRH decreased the cytotoxicity of $\left[\right.$ DLys $\left.^{6}\right]$-LHRH-Curcumin. Each value represents the means \pm S.D. of triplicate determinations in three independent experiments $(* * p<0.01)$. 
A.

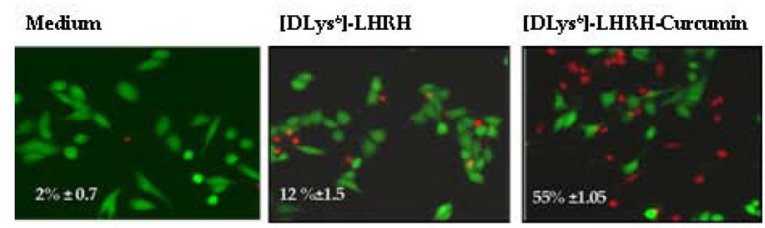

B.
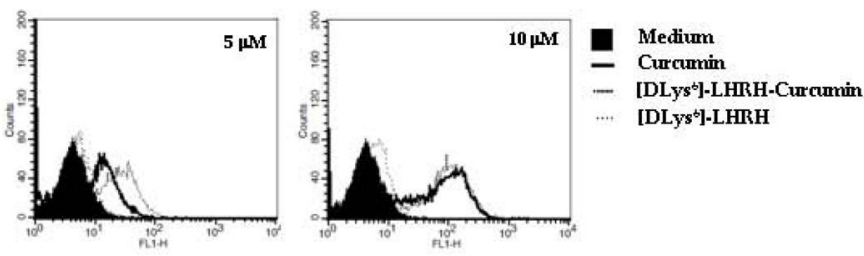

C.

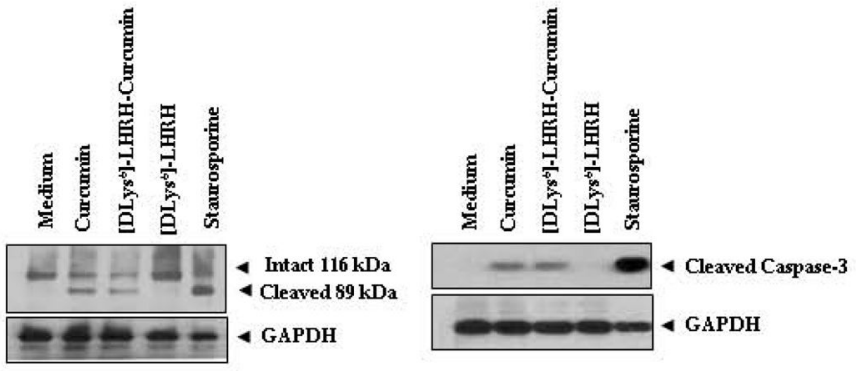

D.

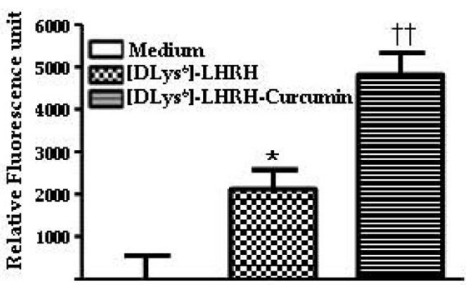

E.

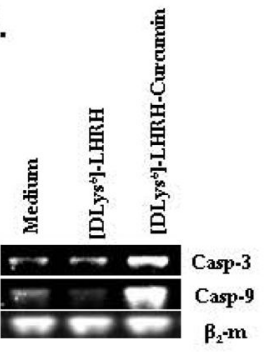

Figure 4.

A. $\left[\right.$ DLys $\left.^{6}\right]$-LHRH-Curcumin induces apoptosis in pancreatic cancer cells. The Live/ dead assay indicates that the percentages of dead cells in medium, medium plus [DLys ${ }^{6}$ ]LHRH, and medium plus [DLys ${ }^{6}$ ]-LHRH-Curcumin in the Live/Dead assay were $2 \pm 0.1,12$ $\pm 1.5,55 \pm 1.5$, respectively. Percentages of apoptotic MIAPaCa- 2 cells are shown.

Apoptotic cells are stained red and live cells are stained green. Values are mean \pm S.E. of triplicate experiments. B, An overlay of FITC-conjugatedAnnexin V staining of MIAPaCa-2 cells after treatment with Curcumin, [DLys ${ }^{6}$ ]-LHRH-Curcumin and [DLys $\left.{ }^{6}\right]$-LHRH for 24 hours. Percent positive cells were evaluated by flow cytometry. Figure represents three independent experiments. C, PARP cleavage and caspase-3 cleavage in [DLys ${ }^{6}$ ]-LHRHCurcumin treated Pancreatic cancer cell, assessed by western blotting. Polyadenosine-5'diphosphate-ribose-polymerase cleavage (right panel). Cleaved caspase-3 after 24 hours of exposure to $10 \mu \mathrm{M}$ Curcumin, [DLys ${ }^{6}$ ]-LHRH-Curcumin and [DLys ${ }^{6}$ ]-LHRH (left panel). Cell lysates were run on 7.5\% SDS-PAGE gels for PARP detection and 10\% SDS-PAGE for cleaved Caspase-3 detection, as described in Materials and Methods. D, The Apo-ONE 
Homogenous Caspase-3/7 assay indicates that [DLys $\left.{ }^{6}\right]$-LHRH-Curcumin induces apoptosis in pancreatic cancer cells. MIAPaCa-2 (10,000 cells/well) were untreated (medium alone), treated with $5 \mu \mathrm{M}$ [DLys ${ }^{6}$ ]-LHRH or $5 \mu \mathrm{M}$ [DLys ${ }^{6}$ ]-LHRH-Curcumin for $24 \mathrm{~h}$. After $24 \mathrm{~h}$ the excitation at 499/emission at 512 was recorded on FlexStation from Molecular Devices (Sunnyvale, CA) with softMax Pro version 4.8 software. E, [DLys ${ }^{6}$ ]-LHRH-Curcumin activate caspase- 3 and caspase- 9 gene expression in pancreatic cancer cells. MIAPaCa-2 cells were incubated with or without $2.5 \mu \mathrm{M}$ [DLys $\left.{ }^{6}\right]-\mathrm{LHRH}$ or [DLys ${ }^{6}$ ]-LHRH-Curcumin for $24 \mathrm{~h}$. Reverse-transcription polymerase chain reaction products of genes encoding caspase-3, caspase- 9 and $\beta 2-\mathrm{m}$ are shown. The image represents the results of three independent experiments. 
A.

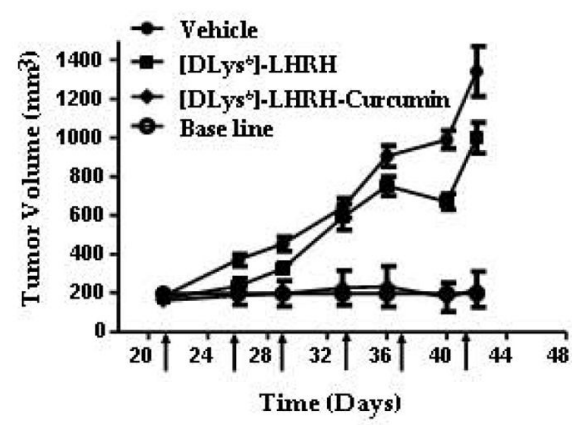

C.

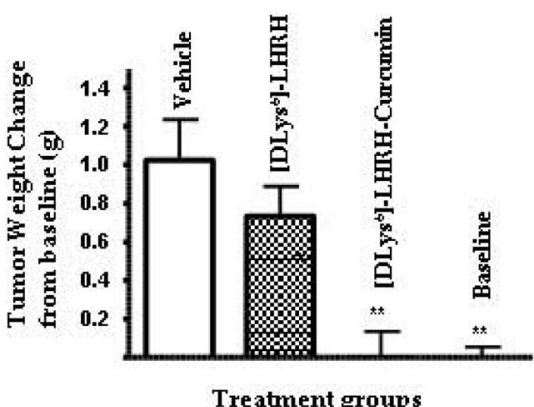

B.

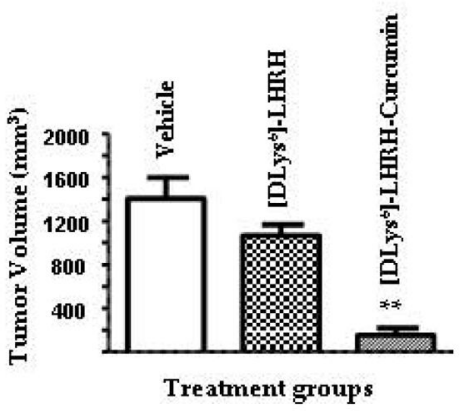

D.

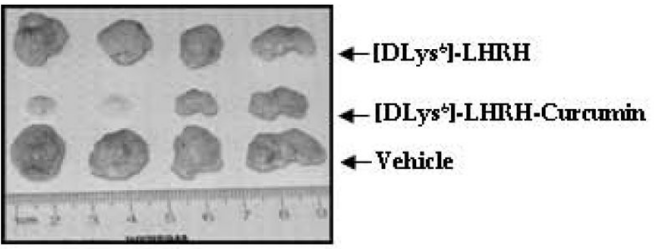

Figure 5. [DLys $\left.{ }^{6}\right]-$ LHRH-Curcumin prevents the growth of human pancreatic cancer cells in vivo

A, Changes in tumor volumes in nude mice receiving twice weekly intravenous injections of PBS (vehicle controls), [DLys ${ }^{6}$ ]-LHRH $\left(2 \mathrm{mg} / \mathrm{Kg}\right.$ ) or [DLys ${ }^{6}$ ]-LHRH-Curcumin (60 mg/

$\mathrm{Kg}$ ). The changes in tumor volume are compared to a baseline volume obtained from a group of tumor bearing mice necropsied prior to the beginning of treatments. Data are presented as the mean \pm S.E. of tumor volume $(n=8)$. B, Tumor volumes at necropsy. The data represent mean \pm S.E. $(n=8)$. Tumor volume at necropsy was significantly reduced $(* *$ $\mathrm{p}<0.01)$ in $\left[\mathrm{DLys}^{6}{ }^{6}\right.$-LHRH-Curcumin treated mice compared to [DLys ${ }^{6}$ ]-LHRH and vehicle treated groups. $\mathbf{C}$, tumor weight changes from baseline measured at necropsy. $\left[\right.$ DLys $\left.^{6}\right]$-LHRH-Curcumin treated and baseline values were significantly $(* * p<0.01)$ lower than [DLys $\left.{ }^{6}\right]-$ LHRH and vehicle treated mice, but did not differ from one another. D, Representative tumors from vehicle treated, [DLys ${ }^{6}$ ]-LHRH treated and [DLys ${ }^{6}$ ]-LHRHCurcumin treated animals. The reduced size of tumors from [DLys $\left.{ }^{6}\right]-$ LHRH-Curcumin $^{2}$ treated mice is evident. 
A.

B.

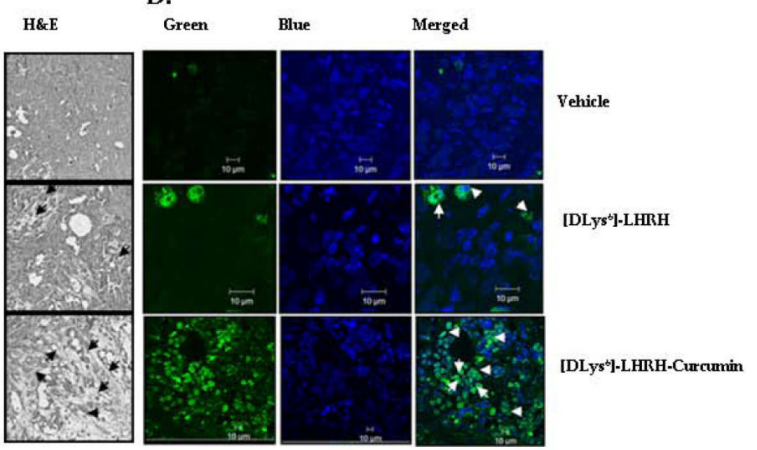

C.

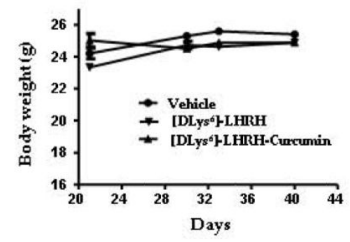

D.

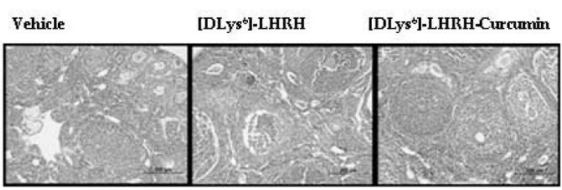

Figure 6.

A, H\&E staining of tumor sections. Representative micrographs of tumors from vehicle, $\left[\right.$ DLys $^{6}$ ]-LHRH treated and [DLys ${ }^{6}$ ]-LHRH-Curcumin treated mice showing increased cell necrosis in [DLys $\left.{ }^{6}\right]-$ LHRH-Curcumin treated with respect to vehicle and [DLys ${ }^{6}$ ]-LHRH treated control. Hematoxylin and eosin stain, (magnification, $100 \mathrm{x}$ ). Arrows indicate necrotic cells. B, Representative confocal photomicrographs of apoptosis detected by TUNEL assay of tumors from mice treated with vehicle, [DLys ${ }^{6}$ ]-LHRH treated and [DLys ${ }^{6}$ ]-LHRH-Curcumin, (magnification, $400 \mathrm{x}$ ); nuclei (DAPI stain), TUNEL-positive nuclei (green stain). C, Body weights of animals treated [DLys ${ }^{6}$ ]-LHRH-Curcumin. There were no significant differences between body weights of vehicle treated controls and [DLys ${ }^{6}$ ]-LHRH-Curcumin treated animals. D, Photomicrographs of ovaries of vehicle treated, [DLys $\left.{ }^{6}\right]-$ LHRH treated and $\left[\right.$ DLys $\left.^{6}\right]$-LHRH-Curcumin treated mice. All three groups contain normal primary, secondary and tertiary follicles and corpora lutea (magnification $100 \mathrm{x}$ ). 